\title{
Effect of Phyllosphere Application of Methylobacterium on Growth and Yield of Barnyard Millet (Echinochloa frumentacea Var. COKV 2)
}

\author{
R. Poorniammal ${ }^{1 *}$, S. Prabhu ${ }^{1}$, M. Senthilkumar ${ }^{2}$ and K. Anandhi ${ }^{3}$ \\ ${ }^{1}$ Horticulture College and Research institute, TNAU, Periyakulam, India \\ ${ }^{2}$ Agricultural College and Research Institute, TNAU, Eachankottai, Thanjavur, India \\ ${ }^{3}$ Agricultural College and Research Institute, TNAU, Madurai, India \\ *Corresponding author
}

\section{A B S T R A C T}

\section{Keywords}

Barnyard millet, Methylobacterium,

Phyllosphere spray,

Seed imbibitions,

Plant growth

promotion

\section{Article Info}

Accepted:

15 March 2020

Available Online:

10 April 2020
Methylobacterium as a ubiquitous symbiont in phylloplane and its influence on crop growth at various stages. This Pink-pigmented facultative methylotrophic bacteria (PPFMs) strains isolated from the phylloplane of Echinochloa frumentacea. A field experiment was conducted to study the effect of Methylobacterium with combination of treatments viz., seed imbibition, soil application and phyllosphere spray in kudiraivali under dryland conditions. This treatment was imposed at 30 and 60 days after sowing. Observations on phylloplane microbial population, plant growth and yield characters were recorded to study the effect of the treatments. Results revealed that, treatment $\left(\mathrm{T}_{6}-\right.$ Seed Imbibition $+1 \%$ Foliar spray of Methylobacterium at $30 \& 60$ DAS) recorded the highest yield of $1251 \mathrm{Kgs} / \mathrm{ha}$. This treatment also increased the yield parameters like number of productive tillers $(8.3 \mathrm{Nos})$, plant height $(183 \mathrm{~cm})$, days to $50 \%$ flowering (48days), No of productive tillers (8.0 Nos), panicle length $(23.6 \mathrm{~cm})$ and days to maturity (33 days) ) and straw yield (2863kg/ha) were also recorded in the treatment. This treatment is followed by $\mathrm{T}_{12}$ (Seed Treatment $+1 \%$ Foliar spray of Methylobacterium at $30 \& 60 \mathrm{DAS}) 1128 \mathrm{Kg} / \mathrm{ha}$.

\section{Introduction}

Bio-fertilizer can be an important component of integrated nutrients management. Microorganisms that are commonly used as bio-fertilizer components include; nitrogen fixers (N-fixer), potassium and phosphorus solubilizers, growth promoting rhizobacteria
(PGPRs), endo and ecto mycorrhizal fungi, cyanobacteria and other useful microscopic organisms. The use of bio-fertilizers leads to improved nutrients and water uptake, plant growth and plant tolerance to abiotic and biotic factors. These potential biological fertilizers would play a key role in productivity and sustainability of soil and also 
in protecting the environment as eco-friendly and cost effective inputs for the farmer (Itelima et al., 2018).

Plant-associated beneficial microbes are recently attaining greater attention as they play an important role in enhancing the productivity of the crops and also providing resistance against the stress conditions and are known as plant growth promoting microbes (PGPMs) (Yadav and Yadav, 2018). Bacteria of the genus Methylobacterium are also called as, pink-pigmented facultative methylotrophic bacteria (PPFMs). They are strict aerobic, Gram-negative rods, able to grow on C1 compounds. The PGPMs contribute to mitigate the stress conditions by diverse mechanisms. The PGPMs directly enhancing the uptake of the micronutrients, through phytohormones production; fixing of atmospheric nitrogen; $\mathrm{P}, \mathrm{K}$, and $\mathrm{Zn}$ solubilization or indirectly stimulating the immune system against various fungal pathogens by production of various compounds, enzymes, siderophores, antibiotics, osmolytes or improving either texture or structure of the soil (Sivakumar et al., 2018).

Methylobacterium are ubiquitous in nature found in a variety of habitats. Methylotrophs have been reported to influence seed germination and seedling growth by producing plant growth regulators like zeatin and related cytokinins, auxins and to alter agronomic traits like branching, seedling vigour, rooting and heat/cold tolerance. These PPFMs are especially abundant on leaves of field-grown crops averagedabout $10^{6} \mathrm{cfu}$ of PPFMs per leaflet, and typically $>80 \%$ of the viable bacteria recovered from leaves were PPFMs. The occurrence of soil methylotrophs is probably related to the abundance of plant lignin and pectin in soils; these polymers are major potential sources of methanol (Subhaswaraj et al., 2017).
Henceforth, inoculation of Methylobacterial isolates that are able to alleviate drought stress could be preferable in the context of environmentally sustainable agriculture. Keeping all the above points in view, it is proposed to conduct an experiment to study the effect of methylotrophs on growth and yield of kudiraivali.

\section{Materials and Methods}

Field experiment was conducted with Barnyard millet variety Co-KV-2 at Regional Research station, Aruppukottai, Tamil Nadu Agricultural University, Virudhunagar district of Tamil Nadu during Kharif 2016-17. The experiment was designed in RBD with 12 treatments, and three replications. Standard cultural practices were followed as recommended by Tamil Nadu Agricultural University, Coimbatore, Tamilnadu. The data were statistically analyzed and critical differences determined by following Gomez and Gomez, 1984.

\section{The treatment details}

$\mathrm{T}_{1-}$ Un inoculated Control

$\mathrm{T}_{2}-$ Seed Treatment (ST) with Azos + PSB

$\mathrm{T}_{3}$ - Seed Imbibition (SI) with 1\% PPFM (Methylobacterium extorquens)

$\mathrm{T}_{4}-\mathrm{SI}+1 \%$ Foliar spray of PPFM at 30 Days after Sowing (DAS)

$\mathrm{T}_{5}-\mathrm{SI}+1 \%$ Foliar spray of PPFM at 60DAS

$\mathrm{T}_{6}-\mathrm{SI}+1 \%$ Foliar spray of PPFM at $30 \& 60$ DAS

$\mathrm{T}_{7}-1 \%$ Foliar spray of PPFM at 30DAS

$\mathrm{T}_{8}-1 \%$ Foliar spray of PPFM at 60DAS

$\mathrm{T}_{9}-1 \%$ Foliar spray of PPFM at $30 \& 60$ DAS

$\mathrm{T}_{10^{-}} \mathrm{SI}+1 \%$ Foliar spray of PPFM at $30 \mathrm{DAS}$ $\mathrm{T}_{11}-\mathrm{ST}+1 \%$ Foliar spray of PPFM at 60DAS $\mathrm{T}_{12}-\mathrm{ST}+1 \%$ Foliar spray of PPFM at $30 \&$ 60 DAS 


\section{Observations}

The following observations viz., microbial population, plant growth parameters were recorded at $30 \mathrm{DAS}, 60 \mathrm{DAS}$, and at harvest. The yield parameters were recorded during harvest.

\section{Enumeration of microbial population and PPFM in leaves}

Enumeration of different microbial population (viz. Bacteria, Fungi, Actinomycetes) were done in their specific media, sterilized in an autoclave at $15 \mathrm{psi}$ pressure and and $121^{\circ} \mathrm{C}$ temperature for 20 minutes using serial dilution spread plating technique (at different intervals of time).

Leaf samples from different treatments were collected after spraying, 30 DAS, and 60 DAS for enumeration of PPFM. The phyllosphere population of PPFM was enumerated by employing serial dilution and plating technique Corpe and Rheem, 1989).

\section{Results and Discussion}

Microbial population of the rhizosphere of Kudiraivali Co-(kv) 2

The microbial population of bacteria was significantly recorded highest at 30 and 60 DAS due to inoculation of bio-fertilizers. The maximum population of bacteria was recorded in the Seed treatment and $1 \%$ phyllosphere spraying of PPFM at $30 \& 60$ DAS (58.00 CFU x $10^{6} \mathrm{~g}^{-1}$ and $111.37 \mathrm{CFU}$ $\mathrm{x} 10^{6} \mathrm{~g}^{-1}$ ) which was on par with $\mathrm{T}_{6}$ and the minimum population was recorded in the control (Table 1). Increased bacterial population in the rhizosphere of kudiraivali plants inoculated with bio-fertilizers is because of inoculation bacterial cultures that would have proliferated in rhizosphere. Hence, in all the stages of plant growth, the microbial population with respect to bacteria has given significant values. In case of fungi and actinomycetes population, also same results obtained at both the stages of plant growth. However, with respect to fungi, highest population was recorded in $\mathrm{T}_{12}$ Seed treatment and $1 \%$ phyllosphere spraying of PPFM at $30 \& 60$ DAS $\left(35.69 \times 10^{-3} \mathrm{cfu} \mathrm{g}^{-1}\right.$ soil and $61.8 \times 10^{-3} \mathrm{cfu}^{-1}$ soil) followed by treatment $\mathrm{T}_{6}\left(34.45 \times 10^{-} \mathrm{cfu} \mathrm{g}^{-1}\right.$ soil and $45.4 \times 10^{-3} \mathrm{cfu}^{-1}$ soil) and minimum in control, with respect to actinomycetes highest population was recorded in Seed treatment and $1 \%$ phyllosphere spraying of PPFM at 30 \& 60 DAS $\left(16.5 \times 10^{-3} \mathrm{cfu} \mathrm{g}^{-1}\right.$ soil and $29.7 \times$ $10^{-3} \mathrm{cfu} \mathrm{g}^{-1}$ soil). Increase in rhizosphere microflora may be attributed to the multiplication of the strains in the rhizosphere, utilizing root exudates produced by the plants (Mohanram and Kumar, 2019) and synergistic interactions between introduced microbial inoculants

\section{Methylobacterium population of the phyllosphere of Kudraivali Co-(kv) 2}

Phyllosphere harbors diverse group of microorganisms and the interaction between the plant and microbes greatly affect the physiological activities of the plant. Pink pigmented facultative methylotrophs (PPFMs) are the prime inhabitants of phyllosphere region of wide variety of plant species (Ochsne et al., 2015; Raja et al., 2008). The present study gives a result suggesting that the Seed imbibition and 1\% phyllosphere spraying of PPFM at $30 \& 60$ DAS maximize the phyllosphere prevalence of PPFM recording an increased population on the leaf at 30DAS $\left(18.42 \times 10^{5} \mathrm{cfu} \mathrm{ml}^{-1}\right)$, and 60 DAS $\left(29.7 \times 10^{5} \mathrm{cfu} \mathrm{ml}^{-1}\right)$ followed by Seed treatment and $1 \%$ phyllosphere spraying of PPFM at $18.12 \times 10^{5} \mathrm{cfu} \mathrm{ml}^{-1}$ ), and 60 DAS $\left(24.8 \times 10^{5} \mathrm{cfu} \mathrm{ml}^{-1}\right)$. PPFMs are highly diversified group of microorganisms abundantly present on the phyllosphere region of several plant species and enhance the plant growth by producing a wide variety of 
phytohormones (Meena et al., 2012; Mizuno et al., 2013). Methylobacterium are symbiotically associated with host plant and regulates host plant growth promotion by producing a number of phytohormones like IAA, cytokinins (Madhaiyan et al., 2012; Dourado et al., 2015) (Table 2).

Table.1 Effect of phyllosphere spray of Methylobacterium on microbial population of the rhizosphere of Kudiraivali Co-(kv) 2

\begin{tabular}{|c|c|c|c|c|c|c|}
\hline \multirow[t]{2}{*}{ Treatments } & \multicolumn{3}{|c|}{30 DAS } & \multicolumn{3}{|c|}{60 DAS } \\
\hline & $\begin{array}{c}\text { Bacteria } \\
\text { CFU } \times 10^{6} g^{-1}\end{array}$ & $\begin{array}{c}\text { Fungi } \\
\text { CFU } \times 10^{3} \mathrm{~g}^{-1}\end{array}$ & $\begin{array}{c}\begin{array}{c}\text { Actino- } \\
\text { bacteria }\end{array} \\
\text { CFU } \times 10^{4} \mathrm{~g}^{-1}\end{array}$ & $\begin{array}{c}\text { Bacteria } \\
\text { CFU } \times 10^{6} \mathrm{~g}^{-1}\end{array}$ & $\begin{array}{c}\text { Fungi } \\
\text { CFU } \times 10^{3} \mathrm{~g}^{-1}\end{array}$ & $\begin{array}{c}\text { Actino- } \\
\text { bacteria } \\
\text { CFU } \times 10^{-1} g^{-1}\end{array}$ \\
\hline $\mathbf{T}_{1-}$ Un inoculated Control & 21.21 & 17.50 & 8.9 & 49.64 & 22.2 & 12.6 \\
\hline $\mathbf{T}_{2}-\mathrm{ST}$ with Azos + PSB & 34.72 & 20.36 & 13.1 & 72.11 & 25.6 & 19.4 \\
\hline $\mathrm{T}_{3}-$ SI with 1\% PPFM & 48.83 & 33.10 & 11.4 & 64.68 & 32.4 & 15.0 \\
\hline $\begin{array}{l}\mathrm{T}_{4}-\mathrm{SI}+1 \% \text { Foliar spray } \\
\text { of PPFM at 30DAS }\end{array}$ & 34.42 & 19.46 & 14.7 & 75.45 & 28.5 & 22.0 \\
\hline $\begin{array}{l}\mathrm{T}_{5}-\mathrm{SI}+1 \% \text { Foliar spray } \\
\text { of PPFM at 60DAS }\end{array}$ & 48.12 & 23.11 & 13.1 & 87.49 & 46.5 & 16.7 \\
\hline $\begin{array}{l}T_{6}-\text { SI }+1 \% \text { Foliar spray } \\
\text { of PPFM at } 30 \& 60 \text { DAS }\end{array}$ & 52.60 & 34.45 & 14.9 & 97.66 & 45.4 & 26.2 \\
\hline $\begin{array}{l}T_{7}-1 \% \text { Foliar spray of } \\
\text { PPFM at 30DAS }\end{array}$ & 34.00 & 23.60 & 10.7 & 52.02 & 36.1 & 18.5 \\
\hline $\begin{array}{l}T_{8}-1 \% \text { Foliar spray of } \\
\text { PPFM at 60DAS }\end{array}$ & 25.00 & 27.54 & 10.7 & 41.57 & 39.3 & 10.4 \\
\hline $\begin{array}{l}T_{9}-1 \% \text { Foliar spray of } \\
\text { PPFM at } 30 \text { \& } 60 \text { DAS }\end{array}$ & 37.00 & 33.10 & 14.7 & 44.64 & 52.5 & 24.8 \\
\hline $\begin{array}{l}T_{10^{-}} \text {SI }+1 \% \text { Foliar spray } \\
\text { of PPFM at } 30 \text { DAS }\end{array}$ & 49.00 & 34.24 & 14.1 & 100.99 & 46.0 & 23.4 \\
\hline $\begin{array}{l}\mathrm{T}_{11}-\mathrm{ST}+1 \% \text { Foliar spray } \\
\text { of PPFM at 60DAS }\end{array}$ & 42.00 & 32.68 & 12.0 & 99.40 & 58.0 & 22.3 \\
\hline $\begin{array}{l}T_{12}-\mathrm{ST}+1 \% \text { Foliar spray } \\
\text { of PPFM at } 30 \& 60 \text { DAS }\end{array}$ & 58.00 & 35.69 & 16.5 & 111.37 & 61.8 & 29.7 \\
\hline SEd & 3.06 & 2.079 & 1.806 & 4.095 & 2.515 & 2.210 \\
\hline CD $(0.05 \%)$ & 6.42 & 4.37 & 3.79 & 8.60 & 5.28 & 4.64 \\
\hline
\end{tabular}


Table.2 Effect of phyllosphere spray of Methylobacterium on population of Kudraivali Co-(kv) 2

\begin{tabular}{|c|c|c|}
\hline \multirow[t]{2}{*}{ Treatments } & \multicolumn{2}{|c|}{ Methylobacterium CFU $\times 10^{5} \mathrm{~g}^{-1}$} \\
\hline & 30 DAS & 60 DAS \\
\hline $\mathbf{T}_{1-}$ Un inoculated Control & 8.52 & 12.5 \\
\hline$T_{2}-$ ST with Azos + PSB & 8.67 & 13.1 \\
\hline$T_{3}-$ SI with $1 \%$ PPFM & 10.12 & 17.5 \\
\hline $\mathrm{T}_{4}-\mathrm{SI}+1 \%$ Foliar spray of PPFM at 30DAS & 17.23 & 22.5 \\
\hline$T_{5}-$ SI + 1\% Foliar spray of PPFM at 60DAS & 10.45 & 23.2 \\
\hline $\mathrm{T}_{6}-\mathrm{SI}+1 \%$ Foliar spray of PPFM at $30 \& 60$ DAS & 18.42 & 29.7 \\
\hline$T_{7}-1 \%$ Foliar spray of PPFM at 30DAS & 17.45 & 21.2 \\
\hline$T_{8}-1 \%$ Foliar spray of PPFM at 60DAS & 9.47 & 20.2 \\
\hline$T_{9}-1 \%$ Foliar spray of PPFM at $30 \& 60$ DAS & 11.12 & 24.1 \\
\hline $\mathrm{T}_{10^{-}} \mathrm{SI}+1 \%$ Foliar spray of PPFM at 30 DAS & 16.47 & 22.2 \\
\hline $\mathrm{T}_{11}-\mathrm{ST}+1 \%$ Foliar spray of PPFM at 60DAS & 8.47 & 25.1 \\
\hline $\mathrm{T}_{12}-\mathrm{ST}+1 \%$ Foliar spray of PPFM at $30 \& 60 \mathrm{DAS}$ & 18.12 & 24.8 \\
\hline SEd & 1.37 & 4.77 \\
\hline $\mathrm{CD}(0.05 \%)$ & 2.88 & 12.5 \\
\hline
\end{tabular}

Table.3 Effect of phyllosphere spray of Methylobacterium on plant biometric and yield parameters of Kudiraivali Co-(kv) 2

\begin{tabular}{|c|c|c|c|c|c|c|c|}
\hline Treatments & 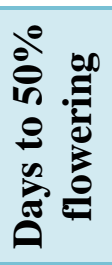 & 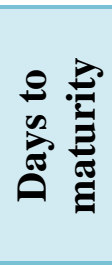 & 氞 & 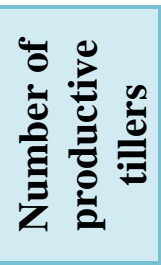 & है & 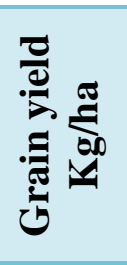 & 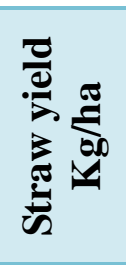 \\
\hline $\mathbf{T}_{1-}$ Un inoculated Control & 56 & 36 & 131 & 4.2 & 14.9 & 660 & 2175 \\
\hline $\mathrm{T}_{2}-\mathrm{ST}$ with Azos + PSB & 56 & 36 & 138 & 5.6 & 16.4 & 680 & 2543 \\
\hline$T_{3}-$ SI with $1 \%$ PPFM & 56 & 36 & 147 & 4.3 & 17.2 & 685 & 1958 \\
\hline $\mathrm{T}_{4}-\mathrm{SI}+1 \%$ Foliar spray of PPFM at 30DAS & 54 & 34 & 142 & 5.8 & 18.1 & 780 & 1934 \\
\hline $\mathrm{T}_{5}-\mathrm{SI}+1 \%$ Foliar spray of PPFM at 60DAS & 54 & 34 & 158 & 5.5 & 18.6 & 812 & 1906 \\
\hline$T_{6}-$ SI $+1 \%$ Foliar spray of PPFM at $30 \& 60$ DAS & 48 & 33 & 183 & 8.3 & 23.6 & 1251 & 2863 \\
\hline $\mathrm{T}_{7}-1 \%$ Foliar spray of PPFM at 30DAS & 55 & 35 & 136 & 6.3 & 20.3 & 943 & 1613 \\
\hline $\mathrm{T}_{8}-1 \%$ Foliar spray of PPFM at 60DAS & 53 & 34 & 146 & 6.7 & 19.0 & 962 & 1698 \\
\hline$T_{9}-1 \%$ Foliar spray of PPFM at $30 \& 60$ DAS & 52 & 34 & 147 & 7.0 & 19.5 & 997 & 1972 \\
\hline $\mathrm{T}_{10^{-}} \mathrm{SI}+1 \%$ Foliar spray of PPFM at $30 \mathrm{DAS}$ & 52 & 34 & 152 & 7.0 & 20.2 & 985 & 1701 \\
\hline $\mathrm{T}_{11}-\mathrm{ST}+1 \%$ Foliar spray of PPFM at 60DAS & 53 & 35 & 162 & 5.3 & 20.8 & 1021 & 2016 \\
\hline$T_{12}-S T+1 \%$ Foliar spray of PPFM at $30 \& 60$ DAS & 50 & 33 & 172 & 8.0 & 22.1 & 1128 & 2675 \\
\hline SEd & 3.528 & 2.83 & 5.40 & 0.96 & 1.821 & 3.123 & 10.345 \\
\hline CD $(0.05 \%)$ & 7.412 & 5.94 & 11.34 & 2.02 & 3.827 & 6.342 & 22.458 \\
\hline
\end{tabular}




\section{Plant growth and yield}

The phyllosphere spraying of PPFM with $1 \%$ concentration at 30 and 60 DAS increased the plant growth and grain yield. As regards to the 2016-2017 trial, the highest yield was recorded with the application of $\mathrm{T}_{6}-75 \%$ RCF + SI and Phyllosphere spray of PPFM $\left(1251 \mathrm{Kgs} / \mathrm{ha}\right.$ ) followed by $\mathrm{T}_{12}$ of $1128 \mathrm{Kg} / \mathrm{ha}$. High yield contributing characters like number of productive tillers (8.3 Nos), plant height $(183 \mathrm{~cm})$, days to $50 \%$ flowering (48days), No of productive tillers (8.0 Nos), panicle length $(23.6 \mathrm{~cm})$ and days to maturity (33 days) ) and straw yield $(2863 \mathrm{~kg} / \mathrm{ha})$ followed by $\mathrm{T}_{12}-\mathrm{RCF}+\mathrm{ST}$ and PPFM $1 \% 30$ DAS and 60 DAS recorded the next higher values while control recorded lower yield of number of productive tillers (8.0 Nos), plant height $(172 \mathrm{~cm})$, days to $50 \%$ flowering (50 days), No of productive tillers (8.0) panicle length $(22.1 \mathrm{~cm})$ days to maturity (33 days) and straw yield (2675 kg/ha) (Table 3$)$.

Madhaiyan et al., (2005) has brought out the beneficial role of phyllosphere PPFM in augumenting the plant productivity. In the present study, increases in the number of PPFMs were positively correlated with the yield increases in kudiraivali.

The beneficial role of PPFMs, when applied as seed inoculant in enhancing germinability, storability or vigour of the seeds was already attributed to their ability to produce the plant growth regulators like Indole acetic acid and ultimately to increased plant growth and yield and also having biocontrol ability (Poorniammal, 2010; Ivanova et al., 2000).

The foliar application of Methylobacterium had significantly improved the overall performance of the tomato plant growth and yield over uninoculated plants (Senthilkumar and Krishnamoorthy, 2017).

\section{References}

Ahmad, F., Ahmad, I., and Khan, M.S. 2008. Screening of free-living rhizospheric bacteria for their multiple plant growth promoting activities. Microbiol. Res., 163:173-181

Corpe, W.A., and Rheem, S. 1989. Ecology of the methylotrophic bacteria on living leaf surfaces.Microb. Ecol., 62: 243-248.

Dourado, M.N., Neves, A.A.C., Santos, D.Z., and Araujo, W.L. 2015. Biotechnological and Agronomic Pote ntial of Endophytic Pink pigmented M ethylobacterium Spp. BioMed Research International.,: 1-19

Gomez, K.A., and Gomez, AA. 1984. Statistical procedure for agricultural research. John Wiley and Sons, New York, USA.PP.680.

Holland, M.A., and Polacco JC. 1994. PPFMs and other covert contaminants: Is there more to plant physiology than just plant? Annu. Rev. Plant Physiol. Plant Mol. Biol., 45: 197-209.

Itelima, J.U., Bang, W..J, Onyimba, I.A., and Egbere, O.J. 2018. Biofertilizer; a key player in enhancing soil fertility and crop productivity. $J$ Microbiol Biotechnol Rep. 2(1): 22-28.

Ivanova, EG., Doronina, N.V., Shepelyakovskaya, A.O., Laman, A,G., Brovko, F.A., and Trotsenko, Y.A. 2000. Facultative and obligate aerobic methylobacteria synthesize cytokinins., Mikrobiologiya., 69 : 764769

Madhaiyan, M., Poonguzhali, S., Lee, H.S., Hari K., Sundaram, SP., and Sa T.M. 2005. Pink-pigmented facultative methylotrophic bacteria accelerate germination, growth and yield of sugarcane clone Co 86032 (Saccharum officinarum L.). Biol. Fertil. Soils., 41: 350-357 
Madhaiyan, M., Poonguzhali, S., Senthilkumar, M., Lee, J.S and Lee, K.C. 2012. Methylobacterium gossipiicola sp. nov., a pink pigmented, facultatively methyltrophic bacterium isolated from the cotton phyllosphere. International Journal of Systematic and Evolutionary Microbiology., 62: 162167.

Meena, K.K., Kumar, M., Kalyuzhnaya, M.G., Yandigeri, M.S., Singh, D.P., Saxena, A.K., and Arora, D.K 2012. Epiphytic pink-pigmented methylotrophic bacteria enhance germination and seedling growth of wheat (Triticum aestivum) by producing phytohormone. Antonie van Leeuwenhoek., 101: 777-786.

Mizuno, M., Yurimoto, H., Iguchi, H., Tani, A., and Saka, I Y. 2013. Dominant colonization and inheritance of Methylobacterium species strain OR01 on Perilla plants. Bioscience Biotechnology and Biochemistry., 77: 1533-1538

Mohanram, S., and Kumar, P. 2019. Rhizosphere microbiome: Revisiting the synergy of plant-microbe interactions. Ann. Microbiol., 69: 307320

Ochsner, A.M., Sonntag, F., Buchhaupt, M., Schrader, J., and Vorholt, J.A. 2015. Methylobacterium extorquens: methylotrophy and biotechnological applications. Applied Microbiology and Biotechnology., 99: 517-534.2.

Poorniammal, R., Sundaram, S.P. and Kumutha,K. 2010. In vitro biocontrol activity of Methylobacterium extorquens against fungal pathogens. Inter. J. Plant Prot., 2(1): 59- 62

Raja, D., Sivasankari, B., and Thilagavathy, D. 2008. Bioefficacy of Methylobacteriurn spp. isolated from various leaf samples on the growth performance of black gram, Vigna mungoL. walp. Journal of Current Science., 12: 735-740.

Senthilkumar, $\mathrm{M}$ and Krishnamoorthy $\mathrm{R}$. 2017. Isolation and Characterization of Tomato Leaf Phyllosphere Methylobacterium and their Effect on Plant Growth. Int.J.Curr.Microbiol.App.Sci., 6(11) : 2121-2136.

Sivakumar, R., Chandrasekaran, P., Srividhya, S., and Vijayakumar, M. 2018. Impact of Pink-Pigmented Facultative Methylotroph on Physiological, Growth Analytical Traits and Yield of Tomato (Solanum lycopersicum) Under Drought Condition. International Journal of Microbiology Research.,10 (5) : 12051208

Subhaswaraj, P., Jobina, R., Parasuraman, P., and Siddhardha, B. 2017. Plant Growth Promoting Activity of Pink Pigmented Facultative MethylotrophMethylobacterium extorquens MM2 on Lycopersicon esculentum L. J App Biol Biotech., 5(01): 042-046.

Yadav, AN., and Neelam Yadav. 2018. Stress-Adaptive Microbes for Plant Growth Promotion and Alleviation of Drought Stress in Plants. Acta Scientific Agriculture., 2(6): 85-88.

\section{How to cite this article:}

Poorniammal, R., S. Prabhu, M. Senthilkumar and Anandhi, K. 2020. Effect of Phyllosphere Application of Methylobacterium on Growth and Yield of Barnyard Millet (Echinochloa frumentacea Var. COKV 2). Int.J.Curr.Microbiol.App.Sci. 9(04): 1860-1866. doi: https://doi.org/10.20546/ijcmas.2020.904.219 